\title{
Project Risk Based Evaluation for Infrastructure Works in Qatar: Highway Projects
}

\author{
Nor Rozaini Abd Rahman \\ nabdrahman@ashghal.gov.qa \\ Public Works Authority (Ashghal), Doha, Qatar
}

\begin{abstract}
The implementation of a project for infrastructure works such as highways, bridges, flyovers, underpasses, tunnels, etc. can be complexed and unique. This has always required a proper project management system that includes the conception and initiation, planning, execution, performance/monitoring and close-out phases. The construction risks identification and mitigation processes are critical and essential at the beginning of the project phase i.e. planning phase, in order to deal with the risks and avert them as to minimize effects to the work progress. The construction risks include additional works that could contribute to the project cost overrun and delay the works progress, any political uncertainty including a blockade imposed by a group of countries towards a particular country, and a possibility of introduction of new taxation by the government i.e. Value Added Tax (VAT) which could definitely affect the material, labor, service and machinery prices. This research paper identifies the construction risks which have affected the implementation of certain ongoing and completed infrastructure works undertaken by the Public Works Authority (PWA or ASHGHAL) in Qatar in recent years. The research included and focused on the importance of project evaluation formalization through identification of obstacles and challenges associated with project risks. There could be a possibility that the identified projects were not fully assessing the significant risk factors during the feasibility studies. Based on a literature review, questionnaires, structured interviews, unstructured interviews, and detailed case studies, it has been established that the most critical construction risks were the design changes, additional works, land acquisition, new requirements, contractors' non-performance, and interfacing works. Most of the experts indicated that the design changes could be reduced by defining and establishing detailed scope of works and specifications during the design stage. An early project coordination with the key stakeholders should be implemented to ensure that the detail information, requirements and any future interfacing works are assessed and updated for potential clashes and resolutions.
\end{abstract}

Keywords: Construction risk; Project evaluation; Infrastructure works; Highway projects; Qatar

\section{INTRODUCTION}

Highway projects are much more than asphalt, concrete, structure or steel works. They are considered as a backbone of the country economy and development apart from providing better transportation links to the people and end users. Efficient highway networks will enable smooth transportation for the people, goods and services to commute inter and intra states, cities, commercial areas, economic zones, ports and airports. A high 
quality highway network system has always been one of the prerequisites for a country to organize any large international events including world sporting championships or tournaments. Qatar is preparing to organize the Federation Internationale de Football Association or International Federation of Association Football (FIFA) World Cup in the year of 2022. ASHGHAL has been mandated to undertake the responsibilities of implementation and completion of the highway projects including the North, South and Orbital expressway programmes with a value of more than USD 8 billion.

\section{RESEARCH OBJECTIVE}

This research began with the objective of identifying the construction risks in highway projects based on the completed and on-going projects. After analyzing the detail case studies, reviewing the literature and conducting interview with the experts (mostly the highway project engineers and managers), the followings objectives were highlighted:

i. To identify the most critical and extreme construction risk which need to be addressed on priority basis.

ii. To define the mitigation risks in the early stage of the construction works.

iii. To establish the project evaluation process model to be practiced in highway projects in Qatar.

\section{RESEARCH METHODOLOGY}

\subsection{Questionnaires}

The data obtained from the literature review and case studies had provided a basis for designing the questionnaires, which were distributed into fifty (50) experts i.e. focusing on the Civil Engineers, Quantity Surveyors and Contract Specialists from PWA. The questionnaires have also been forwarded to PWA' Project Management Consultants (PMC) staff. Out of Fifty (50) experts who were approached directly by the researcher either by-hand or by electronic mail, only 31 responses were received, giving a success rate of 62 per cent.

\subsection{Structured Interviews and Unstructured Interviews}

Structured Interviews participants were selected and conducted only with the experts who were involved directly in the implementation of highways projects. Some of the questions from the same questionnaires were used to explore more on the construction risk and mitigation plans being implemented in their projects. Therefore, twelve (12) interview sessions involving the middle to upper management personnel from PWA, and PWA's PMC were carried out within the months of October and November 2019.

A second group of unstructured interviews were organized in order to elaborate on certain issues, other than the construction risks, especially related to the blockade, which was considered as a new project risk, and also the probability of imposition of a new taxation i.e. the Value Added Tax (VAT). These would extensively need some mechanisms and methodologies to avoid any potential additional claim from the contractors to PWA in the current scenarios and future contracts.

\subsection{Detailed Case Studies}

Four mega highways projects were studied and analyzed to determine the construction 
risks involved and affected the project implementation related to cost overrun and delays to contracts.

\section{FINDINGS}

\subsection{Case Studies of Four Highway Projects}

Project A involved with reconstruction and upgrading the existing highway including interchanges that consisted of tunnels, underpasses, flyovers, junctions and two marine bridges. This project also involved the construction of the Light Rail Transit (LRT), tunnel extension and massive utilities diversion works. Project B's contract associated with upgrading of the existing road related to construction of bridges, tunnels, substations, interchanges, utilities and interfacing works with Qatar Rail.

Project $\mathrm{C}$ involved with design, construct and complete the North Road enhancements including to carry out the waterline and Treatment Sewerage Effluent (TSE) works. The scope of works for Project D associated with the construction and upgrading the existing road which included the construction of bridges, underpasses, tunnels, junctions, existing utilities and landscaping works.

Table 1: Risk Assessment of Four (4) case studies for Highway Projects

\begin{tabular}{|c|c|c|c|c|c|c|}
\hline \multirow{2}{*}{$\begin{array}{c}\text { Descriptions of } \\
\text { Construction Risks }\end{array}$} & \multirow{2}{*}{$\begin{array}{l}\text { Probability } \\
\text { Score }\end{array}$} & \multicolumn{4}{|c|}{ Cost Impact \& Time Impact (Prolongation Cost) } & \multirow{2}{*}{$\begin{array}{l}\text { Level of } \\
\text { Risk }\end{array}$} \\
\hline & & $\begin{array}{c}\text { Project A } \\
\text { Cost Increase }\end{array}$ & $\begin{array}{c}\text { Project B } \\
\text { Cost Increase }\end{array}$ & $\begin{array}{c}\text { Project C } \\
\text { Cost Increase }\end{array}$ & $\begin{array}{c}\text { Project D } \\
\text { Cost Increase }\end{array}$ & \\
\hline Design Changes & 4 & $300-500 \mathrm{mil}$ & 20-100 mil & 5-20 mil & 5-20 mil & Extreme \\
\hline New Requirements & 4 & $50-100 \mathrm{mil}$ & $50-100 \mathrm{mil}$ & $5-20 \mathrm{mil}$ & $5-20 \mathrm{mil}$ & Extreme \\
\hline Land Acquisition & 4 & $50-100 \mathrm{mil}$ & $5-20 \mathrm{mil}$ & 5-20 mil & 20-100 mil & Extreme \\
\hline Interfacing Works & 4 & $50-100 \mathrm{mil}$ & $5-20 \mathrm{mil}$ & 5-20 mil & $5-20 \mathrm{mil}$ & Extreme \\
\hline Additional Scope of Works & 4 & $100-500 \mathrm{mil}$ & $100-500 \mathrm{mil}$ & 100-500mil & $100-500 \mathrm{mil}$ & Extreme \\
\hline $\begin{array}{l}\text { Non-Performance of the } \\
\text { Contractors }\end{array}$ & 3 & 20-50 mil & $5-20 \mathrm{mil}$ & $0-10$ mil & $20-50 \mathrm{mil}$ & High \\
\hline $\begin{array}{l}\text { Availability of Materials, } \\
\text { Labors and Machineries }\end{array}$ & 2 & $5-20 \mathrm{mil}$ & $5-20 \mathrm{mil}$ & $5-20 \mathrm{mil}$ & $5-20 \mathrm{mil}$ & Medium \\
\hline $\begin{array}{l}\text { Physical Geography and } \\
\text { Soil Conditions }\end{array}$ & 2 & $5-20 \mathrm{mil}$ & $5-20 \mathrm{mil}$ & $5-20 \mathrm{mil}$ & $5-20 \mathrm{mil}$ & Medium \\
\hline $\begin{array}{l}\text { Blockade from } \\
\text { Neighboring Countries }\end{array}$ & 2 & 5-20 mil & $5-20 \mathrm{mil}$ & $5-20 \mathrm{mil}$ & $5-20 \mathrm{mil}$ & Medium \\
\hline $\begin{array}{l}\text { Fluctuation of Labor \& } \\
\text { Materials Price }\end{array}$ & 1 & 0-10 mil & $0-10 \mathrm{mil}$ & $0-10 \mathrm{mil}$ & $0-10 \mathrm{mil}$ & Low \\
\hline
\end{tabular}

The researcher has developed the risk assessment as stated in Table 1. This was to identify the level of project risk affected the projects by approaching the most popular method of risk management i.e. the "Risk Matrix" model which adopted the probability/ likelihood of occurrence and the impact/consequences. The risk assessment had been adjusted to suit the information such as the increased of cost considered as an impact to the projects. Furthermore, this method was using both the qualitative variables and quantitative variables. The probability (Score) of occurrence was derived from the opinion, judgement and professional experiences of the experts, questionnaire's result, Variation Order (VO) tracker and the monthly progress report to determine the level of uncertainty and risk associated with the projects. Whereas, to ensure the accuracy 
of the cost impact (Cost increase), the information was obtained from the VO detail submission, VO tracker and based on the researcher's observation and evaluation for having five (5) years of working experiences directly involved with contractors' VOs and consultants' addendum for the PWA's highway projects. The result from Table 1 shown that the "Design Changes", "New Requirement' "Land Acquisition", "Interfacing Works' and "Additional Scope of Works are considered the extreme risks.

\subsection{The Ranking of Severity Impact of the Construction Risks for Highway Projects}

A questionnaire containing a question of severity impact of the construction risks to the implementation of highways projects in Qatar, which includes the respondents' opinion on the risk consequences for construction project performance measures. The result is established based on the construction risks as listed in Table 2; the author developed a method by multiplying the number of respondents to the score number. Based on this approach hierarchical ranking of construction risks in Table 2 shown that the "Design Changes" as the most severe construction risk, followed by the "New Requirements", "Land Acquisition", Non Performance of Contractors" and "Interfacing Works" which were tremendously impacting the cost overrun and caused the delay for the completion of highway projects in Qatar.

Table 2: Severity Impact of the Construction Risk for highway projects in Qatar

\begin{tabular}{|c|l|c|c|c|c|c|c|}
\hline No & \multicolumn{1}{|c|}{$\begin{array}{c}\text { Descriptions of Construction } \\
\text { Risks }\end{array}$} & $\begin{array}{c}\text { Extreme } \\
\text { score } \\
4\end{array}$ & $\begin{array}{c}\text { High } \\
\text { score } \\
3\end{array}$ & $\begin{array}{c}\text { Medium } \\
\text { Score } \\
2\end{array}$ & $\begin{array}{c}\text { Low } \\
\text { score } \\
1\end{array}$ & $\begin{array}{c}\text { Total } \\
\text { score }\end{array}$ & Ranking \\
\hline 1 & Design Changes & 14 & 15 & 2 & 0 & 105 & 1 \\
\hline 2 & New Requirements & 7 & 18 & 6 & 0 & 94 & 2 \\
\hline 3 & Land Acquisition & 14 & 7 & 6 & 4 & 93 & 3 \\
\hline 4 & Interfacing Works & 4 & 17 & 10 & 0 & 87 & 5 \\
\hline 5 & Additional Scope of Works & 4 & 17 & 9 & 1 & 86 & 6 \\
\hline 6 & Non Performance of the Contractors & 6 & 15 & 9 & 1 & 88 & 4 \\
\hline 7 & Availability of Materials, Labors \& Machineries & 3 & 15 & 11 & 2 & 81 & 7 \\
\hline 8 & Physical Geography and Soil Conditions & 3 & 5 & 15 & 8 & 65 & 9 \\
\hline 9 & Blockade from Neighboring Countries & 3 & 10 & 13 & 5 & 73 & 8 \\
\hline 10 & Fluctuation of Labor \& Materials Price & 3 & 1 & 18 & 9 & 60 & 10 \\
\hline
\end{tabular}

\subsection{Construction Risks Identifications and Mitigations Based on Project Stages}

The second survey includes the respondents' opinion the possibility of construction risks if they could be identified and mitigated at the early stage to avoid any disruption and obstacles during the construction works. Based on the questionnaires' result as shown in Figure 1, twenty five (25) respondents or $81 \%$ clarified that "Land acquisition" matters would need to be justified and resolved during the "feasibility study" stage. Some Twenty three (23) respondents or 74\% defined that the risk for "Design Changes" could be identified and mitigated during the design stage. In addition, the majority of respondents agreed that the risks of "New Requirements" and "Interfacing Works" would need to be identified and mitigated during the design stage. 


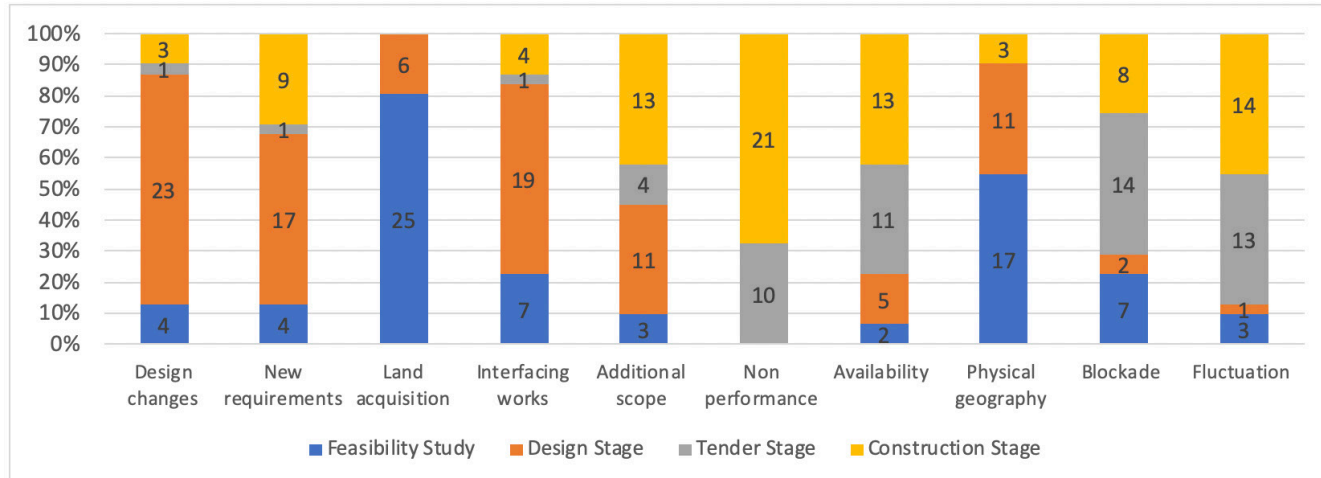

Figure 1: Effective methods of construction risks identifications and mitigations

\section{PROJECT RISK IN HIGHWAY PROJECTS}

\subsection{Design Changes}

Design deficiencies in the construction have led lead to major challenges and adverse consequences to the work progress. It was time consuming to correct the design errors, ambiguities and clashes with other existing utilities or structures before any resolutions can be made to replace any part of the design by revising and issuing the new Issued For Construction (IFC) drawings by the design consultant. Despite the revised IFC drawings due to the LRT realignment, this project had also experienced the revised design drawings due to the massive traffic diversions, revised street lighting works, redesign of storm water network, and upgrade of the designed drainage network. Due to the unclear scope of works, specifications were not detailed and new requirements were later received from either from PWA or other stakeholders. According to Oberlander (2000), the lump sum contracts' changes during the construction stage are a major source of cost overrun. For this type of project, it is necessary to ensure a complete design is fully issued to the contractor to keep any changes, thus consequences to the owner, to a minimum as possible during the construction stage.

\subsection{Land Acquisition}

Land Acquisition issue has caused the disruption to the project program when inability to purchase, own or possess the land would lead to the design changes. For example, a road would need to be diverted or perhaps, to build an underpass or bridge which would affect the project deliverables and cost overrun. Based on the case studies, Project D had been granted a one year of EoT due to the land acquisition issues.

\subsection{New Requirements}

New requirements were either the implementation of instructions or regulations received from either PWA or other key stakeholders. For example, PWA had instructed the contractors to change the asphalt paving works with Polymer Modified Bitumen (PMB). This issue that was raised by PMC on $21^{\text {st }}$ February 2016 defined that "the contractor is instructed to replace the asphalt concrete wearing course and immediate/ binder course of the main carriageway and branch roads including structure slab portion 
with PMB." Another new regulation from a key utility service provider was on the imposed additional requirements on the $66 \mathrm{kV}$ and $132 \mathrm{kV}$ electrical cabling works for Project A which had increased the cost to about USD2.7 million.

\subsection{Non Performance of Contractors}

The contractor's organization's capabilities especially on financial resources, experiences, competencies, technologies, leaderships and decision makings are vital and essential factors to perform excellently throughout its contract duration to deliver the completed project within the budget and time frame. Referring to the Monthly Project Report for project A, in January 2019, it listed the top critical risk being that the "delay to project delivery due to poor contractor's performance", and stated that, "As the current contract completion date is expired, cumulative program schedule is supposed to be $100 \%$, however, the actual cumulative work progress is around $96 \%$. Delays are observed from four (4) stations and commissioning of utilities, and to make it worst, the sub-contractors in this project were not performing to the expectation.

\subsection{Interfacing Works}

Integration and interface between other key stakeholders including the Ministry of Municipality and Environment (MME), Ministry of Municipal \& Urban Planning (MMUP), Ministry of Transportation and Communication (MoTC), General Electricity and Water Cooperation (GEWC or KAHRAMAA), Qatar Armed Forces, Amiri Guard, Qatar National Broadband Network (QNBN), Ooredoo, Vodafone, Qatar Civil Defense Department (QCDD), Qatar Petroleum, etc. involved utilizing existing utilities, approval processes and new requirements, whichever is applicable. Late approval processes and request for information from stakeholders that include request for as-built drawings, building and road permitting issues, land acquisition and property interfacing matters have contributed to the major delays to the projects.

Based on Monthly Projects Report in September 2018 indicated that the issues concerned for Project $\mathrm{C}$ when as-built documents submission was not progressed as per plan due to design issues, uncompleted works and insufficient resources. Zou, Zhang and Wang (2007) stated that "incomplete approval and other documents usually occurs due to management weakness of the project routines or the bureaucracy of government. Clients need to establish a competent team to obtain the approval from government agencies and prepare project documents effectively and efficiently."

\subsection{Additional Scope of Works}

According to this research, the additional scope of works occurred due to PWA and stakeholders' requirements and additional new scope of works. Based on the Monthly Project Report in September 2018 for Project B, the contractor had been instructed to carry out entrusted works for one of the stakeholders i.e. Qatar Rail, as a variation to the contract. The contractor had been informed that the Site Instruction (SI) for design work had already been issued however; the SI for construction work has yet to be issued by the client to date. According to Atkinson et al. (1997), Takim and Akintoye (2002) successful construction project performance is achieved, when stakeholders meet their requirements, individually and collectively. However, according to Nguyen et al. 
(2013), de Wit, (1988) stated that measuring success is complex because it depends on the stakeholders' point of view and it is time dependent. One party may acknowledge project as successful, but another may take the opposite view.

\subsection{Availability of Materials, Labors and Machineries}

Analysis of the case study of Project A which Monthly Project Report in September 2018, reported that one of the critical risk identified was "availability of construction material especially bitumen." Oberlander (2000) stated that the unsuccessful procurement of material is a common source of delays during construction. A procurement plan must be included in the project schedule to guide the purchase of contractor furnished material.

\subsection{Blockade}

The sudden political blockade that happened in June 2017 had led to a disruption of work progress to many projects. Purchase Orders (POs) for certain required materials to the suppliers and vendors at those involved countries had to be cancelled and replaced with alternative products from other countries worldwide. For example, vitrified clay (VC) pipes had been replaced with the glass reinforced pipes (GRP) and accessories. The contractors and their new suppliers had successfully arranged the transportation of the alternative products using the diverted routes via sea vessels and airfreights within a few months after the blockade. However, the majority of respondents had agreed that the unexpected blockade could be considered as a moderate project risk.

\subsection{Value Added Tax (VAT)}

Based on the unstructured interviews with the Contract Specialists of PWA, they had highlighted that lately, the query on VAT has been the most favorite question from the tenderers in their tender submissions. Therefore, the mechanisms and strategies to ensure this issue shall properly be managed if the VAT will ever be enforced are that the proper clauses need to be specified in the general Conditions of Contract (CoC). This pre-empt will minimize, if not eliminate, any additional cost to be incurred to PWA.

\section{PROPOSE MODEL OF THE PROJECT EVALUATION PROCESS}

Based on the international entry process model by Abd Rahman et al. (2009), the researcher modified and developed the process model to suit this research. The proposed process model of "the highway projects strategic decision process model" as shown in Figure 2 below as a decision guideline for any highway projects implementation. The first stage during the feasibility study is to identify, analyze and resolute for critical issues that related, but not limited to, land acquisition matters, permitting requirements, stakeholders' identification, and potential barriers, bottlenecks or challenges to the projects. If the outcomes are positive, the project will proceed into the next stage i.e. design stage. Design stage is the phase to ensure that the designs, specifications and scope of works are detailed and clearly defined, established and completed before pursuing into the tender stage. The key stakeholders', service providers' requirements, existing utilities, as-built drawings and all other details shall need to be incorporated in the design drawings.

Documentation process during the tender stage including the compilation of the 
Bill of Quantities (BoQs), drawings, specifications and all the issues such as embargo, VAT, price fluctuations, as-built drawing with specific version programs shall need to be specified in Condition of Contract ( $\mathrm{CoC}$ ) which shall become a part of the Contract Documents. The selection process of the tenderers/contractors will be carried out based on technical and commercial evaluation. Once the contractor is awarded, the construction stage will start immediately.

\begin{tabular}{|c|c|c|c|}
\hline Feasibility Study & Design Stage & Tender Stage & Construction Stage \\
\hline $\begin{array}{c}\text { Identification } \\
\text { analysis \& resolutions }\end{array}$ & $\begin{array}{l}\text { Developing information } \\
\text { \& outcomes accurately }\end{array}$ & $\begin{array}{r}\text { Documentation \& } \\
\text { Selection process }\end{array}$ & Implementation \\
\hline $\begin{array}{l}\text { 1. Land Acquisition } \\
\text { Requirements } \\
\text {-Land purchased } \\
\text { 2. Physical geography \& } \\
\text { Soil condition } \\
\text {-Soil Investigation } \\
\text {-Land surveying } \\
\text { 3. Design \& scope of works } \\
\text { 4. Stakeholders identification } \\
\text { 5. Draft Budget } \\
\text { 6. Project Estimate } \\
\text { 7. Permit requirements } \\
\text { 8. Environmental regulations } \\
\text { 9. Barrier or challenges } \\
\text {-Blockade } \\
\text { 10. Safety rules } \\
\text { 11. Technology } \\
\text { 12. Contract period }\end{array}$ & $\begin{array}{l}\text { 1. Design } \\
\text { completion/accuracy } \\
\text { 2. Design team coordination } \\
\text { 3. Clear Scope of works } \\
\text { 4. as built drawings } \\
\text { from other utilities } \\
\text { 5. New requirements } \\
\text { 6. Detail specifications } \\
\text { 7. Availability of materials, } \\
\text { labors \& machineries } \\
\text { 8. Stakeholders requirements } \\
\text { 9. Contingency }\end{array}$ & $\begin{array}{l}\text { 1. Specific clause-VAT } \\
\text { 2. Specific clause-Embargo } \\
\text { 3. Specific clause - } \\
\quad \text { Fluctuation } \\
\text { 4. Specific Clause- taking over } \\
\text {-As built drawing } \\
\text { 5. Performance of contractor } \\
\text { 6. Complete contract } \\
\quad \text { document } \\
\text { 7. Availability of materials, } \\
\text { labors \& machineries } \\
\text { 8. Stakeholders approval } \\
\text { 9. Contingency }\end{array}$ & $\begin{array}{l}\text { 1. Interfacing } \\
\text { coordination } \\
\text { 2. Leadership \& decision- } \\
\text { making } \\
\text { 3. Early warning tracker } \\
\text { 4. Monthly Progress } \\
\text { Report } \\
\text { 5. Availability of } \\
\text { materials, } \\
\text { labors \& machineries } \\
\text { 6. Schedule progress } \\
\text { update } \\
\text { 7. Contract Settlement } \\
\text {-final settlement } \\
\text {-submission as built } \\
\text { drawings }\end{array}$ \\
\hline
\end{tabular}

Figure 2: Strategic Decision Process Model for Highway Projects

During construction stage, schedule progress of woks is essential to monitor and control, need to be updated based on actual progress at the site which reflecting labors, materials and machineries resources required. According to Memon, et al. (2006) stated that "project progress monitoring and control is one of the most important tasks of construction project management. Every team member needs to know, in a timely and accurate manner, how is the project progressing, where they are currently in comparison to the initially set plans, whether deadlines are met, budgets are safely measured and followed".

\section{CONCLUSION}

Construction risks can be controlled and managed efficiently if they are identified, registered and mitigated as early as possible in the project stages. During the feasibility study and design stages, construction risks particularly project requirements and dealing with uncertainty and unpredictable events related to land acquisition matters, coordination with stakeholders, physical geography and availability of materials, labours and machineries are efficiently managed and controlled in order to achieve project success. PWA, PMC, consultants and contractors are recommended to culturally adopt the risk management for every project either minor or mega projects, and risk transfer by shifting to the right contract's strategy especially "Design and Build" type of procurement and ensure that the contractors shall have the right competent personnel to 
carry out the works.

A project success is normally measured by the evaluation of time, cost and quality. However, a project can be delayed and over budget but still could be considered as a successful project due to the projects are completed with world class high quality, excellent in terms of safety record, and to the expectations and satisfactions of the PWA and stakeholders. One of the highway projects from the case studies in this paper had won the 6th annual Global Best Project ENR 2018 award by Engineering News-Record (ENR), a reputed engineering and construction industry magazine, in the Road/Highway category. Out of twenty (22) projects from fourteen (14) different countries, Global Best Projects had identified, recognised and honoured the project teams i.e. PWA, PMC, consultants and contractor staff behind their outstanding design and construction efforts in order to complete the most challenging highway projects in Qatar.

\section{REFERENCES}

Abd Rahman, N. R., Torrance, J. V. \& Torrance, M. H. (2009). Influential factors impacting international construction. The Case of Malaysian Contractors, Joint Ventures in Construction, Kobayashi, K., Abdul Rashid, K., Ofori, G., Ogunlana, S., Thomas Telford, London, 90-100.

Memon, Z. A., Abd. Majid, M. Z. \& Mustaffar, M. (2006). A systematic approach for monitoring and evaluating the construction project progress. Construction Technology and Management Center (CTMC), Faculty of Civil Engineering, Universiti Teknologi Malaysia, 81310 UTM Skudai, Johor. Journal - The Institution of Engineers, Malaysia, (Vol. 67, No. 3).

Nguyen, T. A., Chovichien, V. \& Takano, S. (2013). Quantitative weighting for evaluation indexes of construction project success by application of structural equation modeling. International Journal of Construction Engineering and Management, 2(3): 70-84.

Oberlender, G. D. (2000). Project management for engineering and construction, Thomas Casson, the USA.

Takim, R. \& Akintoye, A. (2002). Performance indicator for successful construction project performance. 18 $8^{\text {th }}$ Annual ARCOM Conference, 2-4 September 2002, University of Northumbria. Association of Researcher in Construction Management, Vol. 2.545-555.

Zou, P. X. W., Zhang, G. \& Wang, J. Y. (2007). Identifying key risk in construction projects: Life cycle and stakeholder perspectives. Journal of Project Management, 25 601-614. 